\title{
Paleocurrent Analysis of Kolhan Basin: Implications to Paleogeographic Reconstructions
}

\author{
Kasturi Bhattacharyya* and Subhasish Das \\ Risk Management Solutions, Indian Institute of Technology, India
}

Submission: February 12, 2018; Published: March 16, 2018

*Corresponding author: Kasturi Bhattacharyya, Risk Management Solutions, Indian Institute of Technology, Kharagpur, West Bengal, India, Tel: 03222-255-221; E-mail: bhattacharyya.kasturi@gmail.com

\begin{abstract}
The paleocurrent investigation of a basin is one of the preliminary task for understanding paleogeographic reconstructions and fluvial paleo-channels. Correct paleo channel analysis helps in supporting paleotectonic conclusions from petrology and geochemistry. In this paper paleocurrent of Proterozoic Kolhan basin has been calculated from various methods. It reveals the pattern of transport towards the north-west or north-east in the central region of the area. In the southern region it shows prominent north or northeasterly paleocurrent patterns especially in its lower part. The presence of NNE and NNW paleocurrents, in addition to an important current parallel to the NW has also been indicated. The vector means calculated from grain orientation and cross-bedding indicate at least two distinct flow systems, approximately north-westerly and northeasterly directions during the deposition of the siliciclastics. However the overall polymodal nature of the current rose diagrams suggests interaction of factors during the deposition. The mean directions are almost uniform although magnitude of the vector resultants exhibit frequent variation in the different facies.
\end{abstract}

\section{Introduction}

Paleocurrent refers to the current system, which has long vanished but has left imprints on rocks in the form of textural and structural attributes. In sedimentary rocks it is used extensively as aids in the analysis of sedimentary basins and the development of paleogeographic reconstructions. By analyzing the direction of flow in fluvial paleo-channels, deltaic systems and turbidites, the sedimentary facies whether upstream or downstream may be predicted. Reconstructions developed using paleocurrent data along with lithofacies are important in exploration for mineral deposits (e.g., gold and tin placer deposits) and in petroleum exploration (e.g., the trend of channel sandstone reservoirs). Such paleogeographic reconstructions are often simplistic and limited to general statements about the direction of flow and probable position of the source area [1-3].

Paleocurrent data are used frequently in large scale paleogeographic reconstructions as a means of predicting relative positions of facies belts and basin margin, but only in a semi quantitative way. Primary sedimentary structures and textures (grain size) of sediments are the major features that provide information about the medium and mode of transport and energy conditions at the time of deposition. In the present area of investigation, both small and large scale cross-bedding of directional structures are measured systematically in the field and in the laboratory apposition fabric analysis is completed. Based on certain standard figures and formulae paleohydraulic study for different lithofacies is carried out to establish the hydrodynamic conditions of the Kolhan basin. The sedimentary structures are used as clues for understanding the geometries and hydraulics of paleochannels [4-10].

By analyzing the direction of flow in fluvial paleo-channels and deltaic systems, the sedimentary facies whether upstream or downstream may be predicted. Reconstructions developed using paleocurrent data along with lithofacies are important in exploration for mineral deposits (e.g., gold and tin placer deposits) and in petroleum exploration (e.g., the trend of channel sandstone reservoirs). Such paleogeographic reconstructions are often simplistic and limited to general statements about the direction of flow and probable position of the source area.

In the investigated area both small-scale and large-scale cross-bedding of directional sedimentary structures have been systematically measured in the field. Fabric analysis has been carried out in sedimentological laboratory. Based on standard methods a palaeohydraulic study of different lithofacies has been carried out to determine the hydrodynamic conditions of the Kolhan basin [11-13].

\section{Paleocurrent pattern from cross bedding}

Circular histograms (with vector azimuth) showing paleocurrents have been shown in Figure 1. The computed vector mean suggests northwesterly and northeasterly paleoflow. The sector level paleocurrents on the other hand show wide variation ranging from $357^{\circ}$ to $14^{\circ}$ (Table 1 ). Higher 
value of vector strength, with unimodal distribution for most of the sectors suggests predominantly unidirectional sediment transport. A general northwesterly- northeasterly paleoflow was deduced in this study.

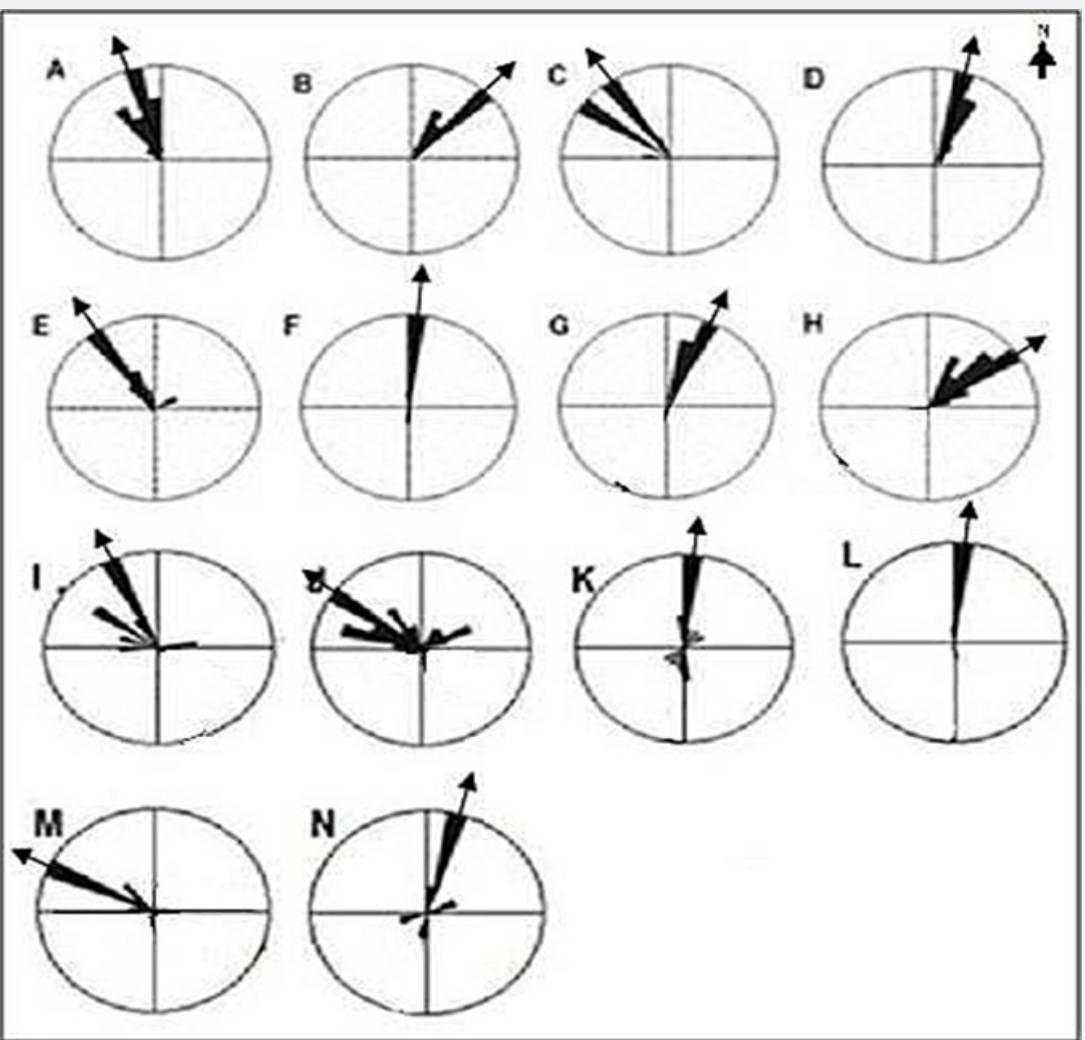

Figure 1: The figure shows the calculated paleocurrent directions.

Table 1: Statistical analyses of paleocurrent data * $(95 \%$ confidence limits of vector means are given in brackets).

\begin{tabular}{|c|c|c|c|c|}
\hline Location & No. of data & Class intervals & Vector mean in Degrees & $\mathbf{9 5 \%}$ confidence intervals in Degrees \\
\hline A & 20 & 10 & 338 & 7.2 \\
\hline B & 15 & 10 & 36.2 & 4.1 \\
\hline $\mathrm{C}$ & 10 & 10 & 311 & 10.2 \\
\hline $\mathrm{D}$ & 8 & 10 & 23 & 5.6 \\
\hline E & 50 & 10 & 339 & 10.2 \\
\hline $\mathrm{F}$ & 8 & 10 & 3 & 29.9 \\
\hline G & 14 & 10 & $19 \& 199$ & 4.3 \\
\hline $\mathrm{H}$ & 17 & 10 & $46 \& 226$ & 13.7 \\
\hline I & 8 & 10 & 138.3 & 36 \\
\hline $\mathrm{J}$ & 21 & 10 & 114.3 & 38 \\
\hline $\mathrm{K}$ & 28 & 10 & 12.2 & 12 \\
\hline L & 14 & 10 & 6.2 & 6 \\
\hline M & 50 & 10 & 111.3 & 19 \\
\hline $\mathrm{N}$ & 7 & 10 & 28.2 & 33 \\
\hline
\end{tabular}

\section{Paleocurrent pattern from prefferred grain orientation}

The percentage frequency distribution of azimuths of detrital quartz in thin section cut parallel to bedding plane, in which the azimuth is grouped into twelve class intervals (Table 2). The statistical operation carried out on the above data includes Tukey chi-square test for preferred grain orientation data and circular arithmetic means. Table 3 \& Table 4 summarize the computational procedure adopted in the present study. Table 5 tabulates the chi-square, preferred grain orientation direction, linear arithmetic mean and circular arithmetic mean for 30 samples studied. 
Table 2: Palelocurrent data from prefered grain orientation.

\begin{tabular}{|c|c|c|c|c|c|c|c|}
\hline Sector name & $\begin{array}{l}\text { No of } \\
\text { observations } \\
\text { (n) } \\
\text { observations } \\
\text { (n) }\end{array}$ & $\begin{array}{c}\text { Vector Mean } \\
\theta(V)\end{array}$ & $\begin{array}{c}\text { Vector } \\
\text { Strength }[R] \%\end{array}$ & $\begin{array}{c}\text { Circular } \\
\text { standard } \\
\text { deviation(s) }\end{array}$ & Variance $\left(s^{2}\right)$ & $\begin{array}{l}\text { Probability of } \\
\text { randomness(p) }\end{array}$ & $\begin{array}{c}\text { Nature of } \\
\text { distribution }\end{array}$ \\
\hline Bistampur & 28 & $14^{\circ}( \pm 11)$ & 87.36 & $28^{\circ}$ & 830 & $<10-9$ & Unimodal \\
\hline Gangabasa & 8 & $316^{\circ}( \pm 23)$ & 91.56 & $23^{\circ}$ & 554 & $<10-2$ & Unimodal \\
\hline $\begin{array}{l}\text { Gumua Gara } \\
\text { river section }\end{array}$ & 14 & $38^{\circ}( \pm 120)$ & 17.96 & $73^{\circ}$ & 5391 & $<10-2$ & Unimodal \\
\hline Matgamburu & 50 & $302^{\circ}( \pm 6)$ & 80.26 & $36^{\circ}$ & 1297 & $<10-13$ & Bimodal \\
\hline Pungsiya & 40 & $357^{\circ}( \pm 59)$ & 59.71 & $51^{\circ}$ & 2648 & $<10-2$ & Bimodal \\
\hline Rajanbasa & 7 & 3 19) & 90.75 & $24^{\circ}$ & 607 & $<10-2$ & Unimodal \\
\hline
\end{tabular}

Table 3: Results of Vector Resultant and Circular Arithmetic Mean of the Directional Structure.

\begin{tabular}{|c|c|c|c|c|c|c|c|c|}
\hline Location & Facies & $\begin{array}{c}\text { Azimuth } \\
\text { of vector } \\
\text { resultant } \\
(\theta \mathrm{V}) \text { in } \\
\text { Degrees }\end{array}$ & $\begin{array}{c}\text { Circular } \\
\text { arithmetic } \\
\text { mean(Z) in } \\
\text { Degrees }\end{array}$ & $\begin{array}{l}\text { Linear } \\
\text { arithmetic } \\
\text { mean }(Y)\end{array}$ & $\begin{array}{c}\text { Circular } \\
\text { standard } \\
\text { deviationin } \\
\text { Degrees (S) }\end{array}$ & $\begin{array}{l}\text { Magnitude } \\
\text { of vector } \\
\text { resultant } ₫\end{array}$ & $\begin{array}{c}\text { Chi-square } \\
(\chi 2)\end{array}$ & $\begin{array}{l}\text { Level of } \\
\text { significance }\end{array}$ \\
\hline $\begin{array}{l}\text { Behind ITI } \\
\text { College(i) }\end{array}$ & SSD,RSD\&TLSD & 337.2 & 282 & 334.5 & 71.42 & 0.22 & 25.69 & 99.5th \\
\hline Surjabasa & Shale & 35.2 & 157.9 & 36.42 & 70.32 & 0.25 & 20.19 & 99.5th \\
\hline Bingtopang & SSD\&TLSD & 311.6 & 81.4 & 312 & 72.01 & 0.32 & 7.03 & 95th \\
\hline Gumuagara & GSD\&SSD & 22.9 & 153.9 & 22.5 & 65.2 & 0.35 & 17.8 & 99.5th \\
\hline Diliyamarcha & SSD & 338.8 & 181.4 & 274.8 & 75.11 & 0.14 & 100.39 & 99.5th \\
\hline $\begin{array}{l}\text { Behind ITI } \\
\text { College(ii) }\end{array}$ & SSD\&TLSD & 2.9 & 135.15 & 78.75 & 65.18 & 0.35 & 13.8 & 99.5th \\
\hline Tunglai & SSD\&PLSD & 29.87 & 181.4 & 274.8 & 69.39 & 0.27 & 100.39 & 99.5th \\
\hline
\end{tabular}

Table 4: Paleohydraulic data from different lithofacies.

\begin{tabular}{|c|c|c|c|c|c|c|}
\hline Facies & GLSD & GSD & SSD & PLSD & RSD & TLSD \\
\hline $\begin{array}{l}\text { Sedimentary } \\
\text { structures }\end{array}$ & $\begin{array}{l}\text { Graded bedding } \\
\text { (no movement) }\end{array}$ & $\begin{array}{l}\text { Trough cross } \\
\text {-bedding }\end{array}$ & $\begin{array}{c}\text { Tabular cross- } \\
\text { bedding and } \\
\text { symmetrical wave } \\
\text { ripples }\end{array}$ & $\begin{array}{c}\text { Parallel } \\
\text { lamination (plane } \\
\text { bed) }\end{array}$ & $\begin{array}{l}\text { Asymmetrical } \\
\text { wave ripples } \\
\text { (large scale } \\
\text { ripples) }\end{array}$ & Small scale ripples \\
\hline Mean size $(\mathrm{mm})$ & $0.25-0.5$ & $0.3-0.5$ & $0.18-0.5$ & $0.21-0.5$ & $0.18-0.5$ & $0.06-0.5$ \\
\hline Median (mm) & $0.35-0.5$ & $0.3-0.5$ & $0.25-0.6$ & $0.21-0.6$ & $0.18-0.5$ & $0.06-0.21$ \\
\hline $\begin{array}{l}\text { Flow velocity } \\
\text { (cm/sec) }\end{array}$ & $82-91$ & $50-60$ & $71-76$ & $71-78$ & $64-66$ & $15-20$ \\
\hline Flow depth (cm) & Dec-18 & $53-77$ & $151-160$ & $150-203$ & $113-123$ & $121-180$ \\
\hline $\begin{array}{c}\text { Mean sediment } \\
\text { discharge }(\mathrm{m} 3 / \\
\text { sec) }\end{array}$ & $1.2-4.9$ & $5.4-13.8$ & $70.6-81.4$ & $70.6-146.6$ & $34.7-43.1$ & $21.3-27.4$ \\
\hline Froude number & 0.19 & 0.22 & 0.18 & 0.18 & 0.19 & 0.16 \\
\hline $\begin{array}{l}\text { Sedimentary } \\
\text { processes }\end{array}$ & Transportation & $\begin{array}{l}\text { Erosion and } \\
\text { transportation }\end{array}$ & $\begin{array}{l}\text { Erosion and } \\
\text { transportation }\end{array}$ & $\begin{array}{l}\text { Erosion and } \\
\text { transportation }\end{array}$ & $\begin{array}{l}\text { Erosion and } \\
\text { transportation }\end{array}$ & $\begin{array}{l}\text { Suspended load } \\
\text { transportation }\end{array}$ \\
\hline
\end{tabular}

Table 5: Estimates of Paleohydrologic Parameters of the Study Area.

\begin{tabular}{|c|c|}
\hline Parameters & Mean Estimate \\
\hline Mean cross-bed set thickness & $0.13 \mathrm{~m}$ \\
\hline Mean water depth (ds) & $1.38 \mathrm{~m}$ \\
\hline Channel width (w) & $61.59 \mathrm{~m}$ \\
\hline Width/depth ratio (F) & 42.97 \\
\hline
\end{tabular}

\begin{tabular}{|c|c|}
\hline Meander wavelength $(\mathrm{Lm})$ & $701.26 \mathrm{~m}$ \\
\hline Mean annual discharge $(\mathrm{Qm})$ & $94.34 \mathrm{~m} 3 / \mathrm{s}$ \\
\hline Channel slope $(\mathrm{Sc})$ & 0.00084 \\
\hline Flow velocity $(\mathrm{v})$ & $0.66 \mathrm{~m} / \mathrm{s}$ \\
\hline Froude number $(\mathrm{Fr})$ & 0.2 \\
\hline
\end{tabular}




\section{Formulae}

The resultant paleocurrent vector $(\theta \mathrm{V})$, vector strength $(R)$, 95\% confidence interval and circular standard deviation (S) were calculated for each location following standard methods.

$$
\begin{aligned}
& \theta V=\tan ^{-1}\left(\sum \sin \theta / \sum \cos \theta\right) \\
& R=1 / n^{*} \sqrt{\left(\left(\sum \sin \theta\right)^{2}+\left(\sum \cos \theta\right)^{2}\right)} \\
& \mathrm{S}=180 / \pi^{*} \sqrt{2}(1-\mathrm{R}) \\
& \text { Where, } \mathrm{n}=\text { number of observation }
\end{aligned}
$$

$\theta=$ paleocurrent direction measured.

The paleocurrent data from grain orientation shows that the direction varies from NE to SW. Such directions should roughly correspond to the paleocurrent directions from cross bedding and ripple marks. The vector mean of cross-bedding data shows the paleoflow from north easterly to north westerly direction. In most cases the data are in rough agreement with the paleocurrent data obtained from apposition fabric analysis. The discrepancies observed at some places are probably due to strong fluctuating nature of the current commonly occurring in shallow basins.

\section{Appossition fabric and paleocurrent data}

Apposition fabric analysis with the help of the fabric of detrital quartz grains has been applied with great prospects in the study of the nature and direction of the transport-agent, of the direction to the source area and in the interpretation of the depositional environment. Although such studies have been mostly applied to lose sands, the utility of the preferred grain orientation analysis in sedimentary rocks has been realized by most workers.

On account of the general paucity of field sedimentary structures in Kolhan Sandstones, emphasis was placed on the grain orientation analysis in thin sections of oriented sandstone samples collected mostly from the northern part of the basin where the bedding and thickness are well represented. The southern half was also sampled as far as practicable in the limited poor outcrops. The method used for apposition fabric analysis consisted in determining the azimuths of about 100 quartz grains in each thin section cut parallel to the bedding plane of about 33 oriented sandstone samples. The total number of quartz grains covered in the present analysis amount to nearly 3500 .

\section{Statistical Analysis}

The statistical operation carried out on the above data includes Tukey chi-square test for preferred grain orientation data and circular arithmetic means. Table 1 summarizes chisquare, preferred grain orientation direction, linear arithmetic mean and circular arithmetic mean for 33 samples studied. The grand preferred orientation direction is found to be $\mathrm{S} 16^{\circ} 49^{\prime} \mathrm{E}$. Figure 1 plots the grain orientation direction in the localities sampled which shows that the direction varies from NE to SW through E and SE. Such directions should roughly correspond to the palaeocurrent directions in the present case, as the rocks are only slightly deformed and the palaeocurrent direction obtained from the scanty sedimentary structures like cross bedding appear to be in rough agreement.

\section{Paleohydraulics}

The channel width(W), meander wavelength(lm), channel depth(d), flow velocity(v), mean sediment discharge(Q) and Froude number(F) have been calculated following standard methods.

$$
\begin{aligned}
& \mathrm{d}=(\mathrm{H} / .086)^{1 / 1.19} \text { in } \mathrm{m} \\
& \mathrm{W}=42(\mathrm{~d})^{1.11} \text { in } \mathrm{m} \\
& \mathrm{lm}=10.9(\mathrm{~W})^{1.01} \mathrm{in} \mathrm{m} \\
& \mathrm{Q}=(\mathrm{lm} / 106.1)^{1 / 0.46} \mathrm{in} \mathrm{m} / \mathrm{s} \\
& \mathrm{v}=\mathrm{Q} / \mathrm{A} \text { in } \mathrm{m} / \mathrm{s} \\
& \mathrm{F}=\mathrm{v} / \sqrt{\mathrm{gd}}
\end{aligned}
$$

Where, $\mathrm{H}$ is average cross-bed set thickness/average ripple height.

\section{A is cross sectional area,}

$\mathrm{g}$ is acceleration due to gravity.

\section{Discussion and Interpretation}

The ultimate aim of sedimentary petrological investigations is to discover the characteristics of the provenance, to discuss the probable mode of dispersal of the clastic constituents and finally to specify the various parameters of the environment of deposition. Reliance is given in such studies on the sedimentary characteristics of clastic particles deposited in known environments.

Keeping in view the limitation of the various methods of environmental analysis as set forth by students of sediments, an attempt is made in the following pages to reconstruct as far as practicable the source area.

The data collected from azimuth reading of cross-bedding and preferred grain orientation analysis are subjected to vector resultant method and circular arithmetic mean method to predict the paleo-flow directions. The statistical procedure carried out on the frequency percent of grain orientation and azimuths of cross-bedding in twelve do decant includes the Turkey's chi ( $\chi 2)$ square test modified after Harrison (1957), Rusnak (1957) and Middleton (1965b, 1967).

The regional distribution of current vectors is shown in Figure 2. It reveals the pattern of transport towards the northwest or north-east in the central region of the area. In the southern region it shows prominent north or northeasterly paleocurrent patterns especially in its lower part. The presence 
of NNE and NNW paleocurrents, in addition to an important current parallel to the NW has also been indicated. The vector means calculated from grain orientation and cross-bedding indicate at least two distinct flow systems, approximately northwesterly and northeasterly directions during the deposition of the siliciclastics. However the overall polymodal nature of the current rose diagrams suggests interaction of factors during the deposition. The mean directions are almost uniform although magnitude of the vector resultants exhibit frequent variation in the different facies.

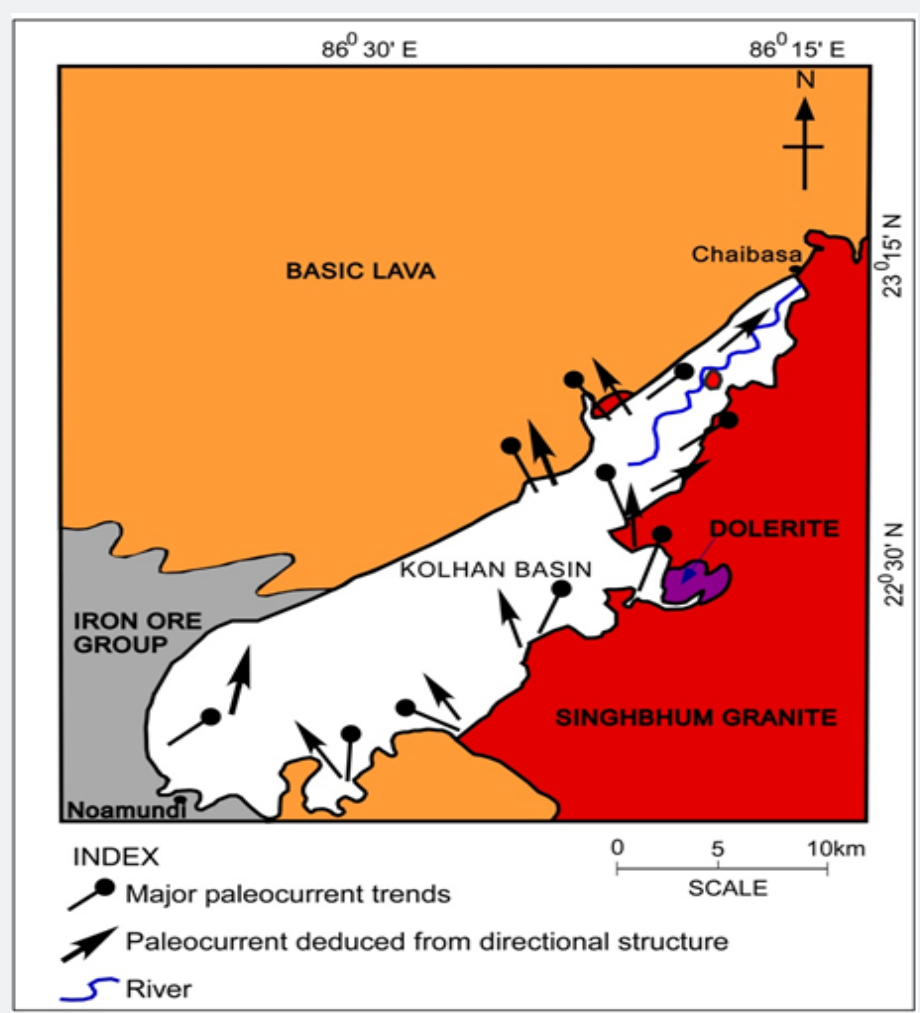

Figure 2: The regional paleocurrent direction in Kolhan basin.

\section{References}

1. Saha AK (1994) Crustal Evolution of Singhbhum-North Orissa. E India Mem Geol Soc Ind 27: 341.

2. Mukhopadhyay D (2001) The Archean nucleus of Singhbhum : the present state of knowledge. Gond Res 4: 307-318.

3. Sarkar SC, Gupta A (2012) Crustal evolution and metallogeny in India, Cambridge University Press, USA, p. 912.

4. Krishnamurthy J, Srinivas G (1995) Role of geological and geomorphological factors in groundwater exploration: a study using IRS LISS data. International Journal of Remote Sensing 16(14) : 25952618

5. Kalluri S, Gilruth P, Bergman R (2003) The potential of remote sensing data for decision makers at the state, local and tribal level: experiences from NASA's Synergy program, Environmental Science Policy 6: 487500.

6. Rachna Raj, Maurya DM, Chamyal LS (1999) Tectonic Geomorphology of Mahi River basin Western India. Journal of Geological Society of India 54: 387-398.
7. Zernitz ER (1932) Drainage patterns and their significance. Jour Geology 40: 498-521.

8. Mahadevan T M (2002) Geology of Bihar and Jharkhand. Geol Soc Ind Spl p. 563.

9. Saha AK (1972) Petrogenetic and structural evolution of the Singhbhum granite complex, Eastern India. Rept. 24 ${ }^{\text {th }}$ Int Geol Cong Sec 2: 149-167.

10. Saha AK (1975) The Mayurbhanj granite-A Precambrian batholith in Eastern India. Geol Soc Ind 16: 37-43.

11. Sarkar SN, Saha AK (1977) The present status of the Precambrian stratigraphy, tectonics and geochronology of Singhbhum-KeonjharMayurbhanj region, Eastern India. Ind Jour Earth Sci, pp. 7-65

12. Bose MK (2009) Precambrian mafic magmatism in the Singhbhum craton, Eastern India. Jour Geol Soc Ind 73(1): 13-35.

13. Mir AR, Alvi SH, Balaram V (2009) Geochemistry, petrogenesis and tectonic significance of the Newer Dolerites from the Singhbhum Orissa craton, eastern Indian shield. International Geology Review 53(1): 46-60. 

(C) Col: $\begin{aligned} & \text { This work is licensed under Creative } \\ & \text { Commons Attribution 4.0 License }\end{aligned}$

\section{Your next submission with Juniper Publishers} will reach you the below assets

- Quality Editorial service

- Swift Peer Review

- Reprints availability

- E-prints Service

- Manuscript Podcast for convenient understanding

- Global attainment for your research

- Manuscript accessibility in different formats ( Pdf, E-pub, Full Text, Audio)

- Unceasing customer service

Track the below URL for one-step submission https://juniperpublishers.com/online-submission.php 